\title{
SUSTAINABLE PERFORMANCE OF PLAYERS IN THE GLOBAL AVIATION INDUSTRY IN THE LIGHT OF MULTI-FACTOR ANALYSIS OF ONLINE REPUTATION
}

\author{
Ludovit Nastisin \\ University of Prešov, Faculty of Management, Prešov, Slovakia \\ Email: ludovit.nastisin@,unipo.sk \\ Beata Gavurova \\ Faculty of Mining, Ecology, Process Control and Geotechnologies, \\ Technical University of Košice, Slovakia \\ Email: beata.gavurova@tuke.sk \\ Radovan Bacik \\ University of Prešov, Faculty of Management, Prešov, Slovakia \\ Email: radovan.bacik@,unipo.sk \\ Nella Svetozarovova \\ University of Prešov, Faculty of Management, Prešov, Slovakia \\ Email: nella.svetozarovova@unipo.sk \\ Richard Fedorko \\ University of Prešov, Faculty of Management, Prešov, Slovakia \\ Email: richard.fedorko@unipo.sk
}

Received: 1 April 2021. Revision received: 10 May 2021. Accepted: 21 May 2021

\begin{abstract}
The issue of reputation management in terms of increasing sustainable performance and competitiveness is rapidly developing and undoubtedly is the most important tool in the business area. The study analyzes the reputation of 10 companies with the largest share in the aviation market that were selected on the basis of one of the most widely-used measures of airline size passenger-kilometer (RPKs) as presented by the International Air Transport Association. The aim is to point out online reputation tools and present ways to improve the performance and competitiveness of analyzed subjects by managing several digital metrics that create this reputation. For this purpose, was applied a modified multi-factor analysis of the overall online reputation sentiment. The research results provide business units with reasonable evidence to proactively implement and invest in reputation management approach because such approach should have a positive impact on their sustainable performance dimensions and further enhance strategic competitiveness.
\end{abstract}

KEYWORDS: Online reputation, Aviation industry, Sustainable performance, Multi-factor analysis.

JEL CLASSIFICATION: L14; L25; M31.

Reference: Nastisin, L., Gavurova, B., Bacik, R., Svetozarovova, N. \& Fedorko, R. (2021). Sustainable performance of players in the global aviation industry in the light of multi-factor analysis of online reputation. International Journal of Entrepreneurial Knowledge, 9(1), 1-9. doi: 10.37335/ijek.v9i1.130

\section{INTRODUCTION}

When tackling the issue of reputation, the concept of performance is becoming more and more important. The question here is the choice of the right parameters or indicators that would make it possible to quantify reputation in the context of overall performance in a way that is appropriate for a particular company. A wide range of factors and criteria, both financial and non-financial, should be taken 


\section{INTERNATIONAL JOURNAL OF ENTREPRENEURIAL KNOWLEDGE}

Issue 1, volume 9, ISSN 2336-2960 (Online)

www.ijek.org

into account. The key factor of success is most often associated with outputs - the result of work. Organizations with good reputation attract investors, competent employees and eco-oriented customers (Morales-Raya et al., 2019 In: Afum et al., 2020). In as much as the advantages of business reputation are lauded, its measurement is relatively difficult. However, many studies (Chun, 2005; Esteban-Sanchez et al., 2017; Štefko et al., 2016) have measured reputation from a multi-dimensional perspective. For the purpose carrying out the multi-factor analysis of online reputation has been choosed the aviation industry. Many studies have assessed the efficiency and competitiveness of airlines and airports in terms of the air transportation industry, but no studies have been found that assessed the comparative advantage of national efficiency from sustainability perspective (Song et al. 2020). Further Song et al. 2020 applyied the competitiveness evaluation methodology for aviation industry sustainability using data envelopment analysis model based on linear programming. We followed up on findings and provided exploration of the link between the online reputation and its implications in the aviation industry with focus on possibilities to increase performance of selected variables by managing its online reputation.

\section{LITERATURE REVIEW}

Ghosh (2017) defines business reputation as intangible and rare resource (assets) that provides companies with superior competitive advantage and considered as a company's most significant strategic resource. Some authors argue that intangible resources are the drivers of organizational performance (Zigan, 2013; Gavúrová \& Šoltés, 2015). Likewise, business reputation - regarded as one of the main intangible resources - is seen as a driver of organizational performance and has received attention from the academy in the last decades (Vance \& De Angelo, 2007). Good reputation can increase customer confidence in their purchasing decision and reduce shopping dissonance, thus leading to increased satisfaction and customer loyalty (Lafferty \& Goldsmith, 1999). Literature further indicates that a good corporate reputation can affect business performance and the inverse relationship is also true (Dowling, 2006; Brown \& Perry, 1994; Carmeli \& Tishler, 2005 In: Pirey \& Trez 2018). The significance of studying sustainable performance in relation to reputation has increased over the years. According to Afum et al. (2018) sustainable performance ensures that firms holistically balance their economic, environmental and social performance goals. Thus, measuring performance from the sustainable point of view helps firms to assess their efforts and achieve improvement regarding environmental and social developments at all levels in their supply chain while simultaneously creating value for its shareholders (Çankaya \& Sezen, 2019 In: Afum et al., 2018). Authors in study explore the link between green manufacturing, operational competitiveness, firm reputation and sustainable performance dimensions. Alon (2015) states that superior sustainability performance has a positive association with sustainability reputation. Companies with better performance are also more likely to obtain external assurance of their sustainability disclosure, but assurance does not directly affect reputation. Authors García de Leaniz \& Rodríguez del Bosque (2014) present relationship between sustainability and corporate image and reputation according to the legitimacy theory framework since the current academic literature does not have an understanding of how sustainability and corporate image and reputation interact.

Fombrun (2004) defines a methodology that aims to measure the consumer's perception of the business reputation. He outlines 20 factors that affect reputation based on 6 criteria, namely emotional factors, products and services, vision and management, social responsibility of the company. Turner (2004) outlines yet another model of reputation factors. Not only does it define the eight main factors of reputation, but also for each of them it also gives information sources that influence them. In addition, these factors are divided into rational and emotional (Turner, 2004). From the viewpoint of defining the factors of virtual reputation, Štefko and Pollák (2016) report that in spite of the huge amount of analyses, many authors believe that reputation is much more important in online than in off-line environment, as the factors determining trust in off-line context are absent and are not yet known. The Reputation 


\section{INTERNATIONAL JOURNAL OF ENTREPRENEURIAL KNOWLEDGE}

Issue 1, volume 9, ISSN 2336-2960 (Online)

www.ijek.org

Institute (2011) has in Reputation model defined a set of seven major factors affecting business reputation: Products, Innovation, Workplace, Governance, Citizenship, Leadership, and Performance. It is a model and system for regular reputation measurement of multinational corporations used by the reputation research company - Reputation Institute. Based on a series of research into reputation, Reputation Institute states that the above-mentioned seven factors have different weights or pyramidlike importance factors, the basis of which is the quality of the goods or services and the associated customer service, followed closely by the integrity of the company (fulfilment of declared promises and ethical behavior), and then all other attributes. In other words, what matters most is a portfolio of products and services, however, commercial variables are not sufficient enough to achieve a good business reputation.

With regard to online reputation management and its development in the conditions of competitive markets, Sasko (2014) states that online reputation monitoring should be an important part of every company's marketing strategy. Thanks to online monitoring, businesses can learn a lot about what their clients, partners, or employees think about them. Revealing bad reputation at the right time can prevent many losses. The fact remains that building a good reputation is a long-term process, losing it, however, may be a matter of only a few seconds. According to Madden and Smith (2010) reputation management has become an integral part and at the same time a distinctive feature not only of the brick-and-mortar companies but also of online businesses, thus giving rise to Search Engine Reputation Management. While some internet users are cautious and focus exclusively on specific target activities, other internet users have open access to information sharing without limitation. Search engines and social networks play a key role in reputation building, whether we are talking about physical person or a business. This means that reputation is very fragile and one mistake can sometimes cause irreparable damage (Pollák, 2015). This is especially true in the digital world ruled by radical transparency and high standards of customers.

The issue of measuring and managing the business reputation is analysed in several disciplines. Reputation management in the segment of transport and logistics was analysed by Zraková et al. (2019) who analysed the impact and consequences of online reputations on business. In his study, Taeuscher (2019) showed that the benefits of reputation depend significantly on business market conditions on a sample of 797,087 transactions from nearly 6,000 businesses on 119 online e-commerce market platforms. Wang and Chen (2020) presented a new online monitoring methodology for detecting reputational attacks in product reviews. Similarly, Ma et al. (2019) proposed a reliable framework for reputation calculation for online products in order to provide reputation calculation as a service in the near future. Furthermore, Dai et al. (2018) presented a method of improved group rating of reputation in the online space. An interesting study came from the authors Oghazi et al. (2020), who found that men and women perceive reputation of online retailers differently. The study by Xu et al. (2018) presented an online model of dynamic feedback incentive (DFI) to be used for reputation management in the online environment. The research of Riquelme et al. (2019) examined the link between retailer reputation and customer loyalty. They found that pricing practices considered unfair can change how loyal customers perceive reputable retailers. Štefko and Pollák (2016) used a multi-factor analysis of online reputation in the segment of tourism, when they examined the reputation of Slovak cities. These findings were further developed in the context of urban marketing in a study by Štefko et al. (2017). According to above mentioned the paper analyses online reputation using the TOR method in order to point out the importance of online reputation and implications it has for increasing sustainable performance and business competitiveness.

\section{METHODOLOGY}

Our research study analyzes the largest players in the global aviation industry. We focus on 10 airlines that were selected on the basis of one of the most widely-used measures of airline size - passenger- 
INTERNATIONAL JOURNAL OF ENTREPRENEURIAL KNOWLEDGE

Issue 1, volume 9, ISSN 2336-2960 (Online)

www.ijek.org

kilometer (RPKs) as presented by the International Air Transport Association (IATA 2019). The companies researched are shown in the following table.

Table 1 Revenue passenger kilometers of 2019 [RPKs]

\begin{tabular}{lcc}
\hline Airline company & RPK [billion] & RPK [\%] \\
\hline American Airline & 3.31 & 14.00 \\
Delta Air Lines & 3.30 & 13.95 \\
United Airlines & 3.30 & 13.95 \\
Emirates & 3.02 & 12.77 \\
Southwest Airlines & 2.15 & 9.09 \\
China Southern & 2.00 & 8.46 \\
Ryanair & 1.71 & 7.23 \\
China Eastern Airlines & 1.66 & 7.02 \\
Air China & 1.61 & 6.81 \\
Lufthansa & 1.59 & 6.72 \\
\hline
\end{tabular}

(Source: Binkley, 2019)

The analysis aimed at identifying online reputation of entities and pointing out the possibilities of managing this reputation in a given segment through influencing selected metrics - the building blocks of this online reputation. To achieve this goal, we implemented a TOR (total online reputation) methodology, which analyzes the overall reputation of the subject in the online space. It was presented by Pollák et al. (2019).

In this process, we work with the search results of selected keywords and the sentiment of these results. In the research we also applied anonymization to eliminate personalized results based on search history. The research presents the results of two levels of this process. "Company business name" was used as the first search phrase, followed by "company business name + travel" in the second phase, which is the most relevant keyword for the segment. In a two-level analysis, each subject can reach an imaginary upper limit of 310 points. As stated by Pollák et al (2019), each point obtained is equal to $0.32 \%$ of the final rating for the ASA score. In the paper, we work only with the resulting values of this partial analysis, as the TOR methodology uses only its final score.

For the TOR analysis, it was further necessary to analyze other determinants of online reputation, the so-called reputators. It is certainly not possible to have unchangeable reputators for this methodology across the board, as each segment has its own specifics and thus the relevance of individual reputators changes. In general, however, a reputation is defined as any determinant that has a valid ability to influence the perception of the subject's reputation in the online space. Their quantification is presented as a competitive reputation score (CS). According to Social bakers (2016), we can calculate such a reputation as the ratio of the number of followers to the total number of followers of all analyzed entities. The analysis ends with the determination of the overall competitive advantage of the investigated subject within the set of investigated subjects. The TOR score is the arithmetic mean of all metrics that enter this methodology. 
INTERNATIONAL JOURNAL OF ENTREPRENEURIAL KNOWLEDGE

Issue 1, volume 9, ISSN 2336-2960 (Online)

www.ijek.org

The calculation process is performed using the following formula:

$$
\begin{gathered}
T O R=\frac{R_{A S A}+\sum_{i=1}^{n} R_{i}}{n+1} \\
\text { where } \mathrm{TOR}-\text { total online reputation in } \%, \\
\mathrm{R}_{\mathrm{i}}-\text { reputators, } \\
\mathrm{R}_{\mathrm{ASA}}-\text { reputators ASA, } \\
\mathrm{n}-\text { number of indicators }
\end{gathered}
$$

We also subjected selected variables to statistical research to identify potentially significant relationships by nonparametric methods (Kendall Tau).

\section{EMPIRICAL RESULTS AND DISCUSSION}

\begin{tabular}{|c|c|c|c|c|c|c|c|}
\hline & & $\begin{array}{c}\text { ASA } \\
\text { score } \\
(\%)\end{array}$ & $\begin{array}{c}\text { IGCS } \\
\text { score } \\
(\%)\end{array}$ & $\begin{array}{c}\text { FBCS } \\
\text { score }(\%)\end{array}$ & $\begin{array}{c}\text { YTCS } \\
\text { score }(\%)\end{array}$ & $\begin{array}{c}\text { PICS } \\
\text { score } \\
(\%) \\
\end{array}$ & $\begin{array}{l}\text { TOR } \\
\text { score }\end{array}$ \\
\hline 1 & American Airline & 10.80 & 9.13 & 5.31 & 5.77 & 6.28 & 7.46 \\
\hline 2 & Delta Air Lines & 9.56 & 9.14 & 6.76 & 7.03 & 2.62 & 7.02 \\
\hline 3 & United Airlines & 8.41 & 6.77 & 2.87 & 4.61 & 6.32 & 5.80 \\
\hline 4 & Emirates & 12.72 & 47.34 & 22.03 & 53.45 & 13.69 & 29.85 \\
\hline 5 & Southwest Airlines & 9.75 & 6.40 & 12.61 & 16.60 & 1.04 & 9.28 \\
\hline 6 & China Southern & 8.99 & 2.00 & 20.98 & 0.11 & 20.85 & 10.59 \\
\hline 7 & Ryanair & 10.13 & 0.88 & 10.26 & 5.70 & 0.52 & 5.50 \\
\hline 8 & China Eastern Airlines & 10.99 & 6.24 & 8.93 & 0.79 & 0.51 & 5.49 \\
\hline 9 & Air China & 8.32 & 0.11 & 2.18 & 0.83 & 47.61 & 11.81 \\
\hline 10 & Lufthansa & 10.33 & 11.99 & 8.06 & 5.12 & 0.57 & 7.21 \\
\hline
\end{tabular}

The survey compared the effeciency of online reputation of the top 10 global airlines with the highest RPK. The ASA score of the analyzed subjects was calculated in the previous step. Now, we work only with the final score.

Table 2 TOR reputation of global airlines

\section{(Source: Authors' results)}

It is clear from the results that Emirates clearly achieved the best online reputation at TOR $=29.85 \%$ among the surveyed group. It dominated four of the five reputable determinants, with those on social media well ahead. Only two other companies have crossed the $10 \%$ reputation mark. In second place is Air China with a score of TOR $=11.81 \%$ and in third place is China Southern with a score of TOR $=$ 10.59\%. Ryanair with 9 TOR $=5.5 \%$ and China Eastern Airlines with TOR $=5.49 \%$ are at the bottom of the table. 


\section{INTERNATIONAL JOURNAL OF ENTREPRENEURIAL KNOWLEDGE}

Issue 1, volume 9, ISSN 2336-2960 (Online)

www.ijek.org

If we look at the results from the perspective of individual determinants, in particular the analysis of the sentiment of search results, the situation is relatively balanced. The whole variance of the achieved score occurs in a deviation of less than $5 \%$. As mentioned, Emirates dominated, but such results declare a fairly balanced factor in the overall online reputation. In the case of the social network Instagram, the leader is way ahead of the analyzed companies - by almost 36\% and almost half of all followers in the group follow Emirates. This dominance is very pronounced here. It is very much the same in the case of the social network Facebook, where, however, the situation is much more balanced and the difference between the first places is just over 1\%. The last determinant of the social media category was Youtube. Once again, a significant lead gap of almost $37 \%$ is present, and we see only a small group of companies that have achieved a competitive result. The last determinant examined was the indexed pages on Google. In this case Air China dominated, owing almost half of the indexed pages and had an advantage over another competitor by over $25 \%$.

Table 3 Social network followers base count

\begin{tabular}{cccc}
\hline All brands & Instagram & Facebook & YouTube \\
\hline Sum of followers $[\mathrm{N}]$ & 11793168 & $\mathbf{4 8 7 2 1 8 2 7}$ & 1305762 \\
\hline
\end{tabular}

(Source: Authors' results)

With an emphasis on social media, Facebook is the best place global airlines to recruit new followers. There we recorded the largest set of potential followers, which was almost 5 times larger than that of Instagram. When we searched for the statistical significance of the relationships between selected determinants of the online reputation of the TOR methodology, we did not record any significance in the relationships. In all cases of Kendall Tau test, the p-value was greater than the established tolerance rate of 0.05 . Based on the above, we state that all determinants act individually and therefore need to be managed in this way. It follows that the size of the airline does not play a role in the online reputation. It also opens up opportunities for smaller competitors to optimize their online presence in order to reduce the distance from their competitors.

\section{CONCLUSIONS}

The issue of business reputation in terms of increasing the sustainable performance and competitiveness is rapidly developing and undoubtedly the most important tool in business area. It is an important asset in terms of building and maintaining a competitive advantage, as well as potential sources of business effectiveness as a whole. The business sector represents one of the most important parts of the modern economy (Fil'a et al., 2020). It is fact, that successful entrepreneurs are socially recognized (Gódány et al., 2021). As already mentioned, reputation is considered by many authors as the asset of an organization, we also face the claim that it is the most complex business asset (Afum et al., 2020; Boyd et al., 2010; Fombrun \& Ponzi, 2016; Fedorko et al., 2018). On the basis of the above mentioned, the main aim of the presented paper was to to explore the link between the online reputation and its implications in the aviation segment and find out whether it is possible to increase sustainable performance and strategic competitiveness of the company by managing its online reputation.

We focused on how companies and managers can in practice manage the reputation of their companies in the online environment and try to correct the current reputation of the company through the 


\section{INTERNATIONAL JOURNAL OF ENTREPRENEURIAL KNOWLEDGE}

Issue 1, volume 9, ISSN 2336-2960 (Online)

www.ijek.org

mentioned determinants, ie reputators. We applied the analysis procedures to a very significant segment for the current market, which are providers of aviation service. We have identified the most prominent players and those whose reputation in the online space is perceived best and achieved the highest TOR score.

On the basis of findings, we can assume, there are several reasons for a holistic approach to the reputation management. For businesses, the most important thing is to realize the meaning and purpose of reputation management: the reason the reputation management is needed, why it is important to manage and evaluate reputation; identify the object of the reputation management, which reputation determinants are to be subjected to management and evaluation; choosing a procedure and methodology, determining how to manage and evaluate reputation; determining the frequency of management and evaluation of reputation in relation to the objectives of the business entity and individual needs of employees; verify the a set of reputation determinants respectively intangible assets in relation to the concept of performance of the providers in online market. However, despite our research, this issue requires further research and a deepening of the basis for knowing which determinants play an important role in this area. This is the direction that future research will take, but there is also an effort to implement qualitative factors, not just quantitative ones. However, we consider the stated goal of the article to be fulfilled.

\section{Acknowledgments}

The paper presents a partial research result of the project KEGA 042PU-4/2020 entitled: Implementation of innovative approaches and teaching materials in the educational process of future managers.

\section{REFERENCES}

Afum, E., Agyabeng-Mensah Y., \& Sun, Z. (2020). Exploring the link between green manufacturing, operational competitiveness, firm reputation and sustainable performance dimensions: a mediated approach. Journal of Manufacturing Technology Management, 31(7), 1417-1438.

Alon, A. (2015). Sustainability Performance and Assurance: Influence on Reputation. Corporate Reputation Review, 18(4), 337-352. doi:10.1057/crr.2015.17

Binkley, R. (2019). These Are the World's Largest Airlines [online]. Retrieved from https://thepointsguy.com/guide/worlds-largest-airlines/

Boyd, B., Bergh, D., \& Ketchen, D. (2010). New frontiers of the reputation-performance relationship: insights from multiple theories. Journal of Management, 36(3), 620-632.

Dai, L. et al., (2018). Identifying online user reputation in terms of user preference. Applications, 494.

Esteban-Sanchez, P., De la Cuesta-Gonzalez, M. \& Paredes-Gazquez, J.D. (2017). Corporate social performance and its relation with corporate financial performance: international evidence in the banking industry. Journal of Cleaner Production, 162(1), 1102-1110.

Fedorko, R., Fedorko, I. Geda, R., Rigelský, M. Oleárová, M., \& Obšatníková, K. (2018). The impact of selected elements of e-commerce to e-shop recommendation. Polish Journal of Management Studies, 18(2), 107-120.

Fil’a, M., Levický, M., Mura, L., Maroš, M., \& Korenková, M. (2020). Innovations for Business Management: Motivation and Barriers. Marketing and Management of Innovations, 4, 266-278.

Fombrun, Ch., Ponzi, L., \& Newsburry, W. (2015). Stakeholder Tracking and Analysis: The RepTrak ${ }^{\circledR}$ System for Measuring Corporate Reputation. Corporate Reputation Review, 18(1), 3-24.

Fombrun, C.J., \& Van Riel, B. (2004). How Successful Companies Build Winning Reputations. FT Press, New Jersey.

García de Leaniz, P. M. \& Rodríguez-del-Bosque, I. (2014). Sustainability Dimensions: A Source to Enhance Corporate Reputation. Corporate Reputation Review, 17(4). doi:10.1057/crr.2014.13 


\section{INTERNATIONAL JOURNAL OF ENTREPRENEURIAL KNOWLEDGE}

Issue 1, volume 9, ISSN 2336-2960 (Online)

www.ijek.org

Gavurová, B., \& Šoltés, M. (2015). Modification of performance measurement system in the intentions of globalization trends. Polish Journal of Management Studies, 11(2), 160-170.

Ghosh, S.K. (2017). Green supply chain management in production sectors and its impact on firm reputation. Journal of New Theory, 18(1), 53-63.

Godany, Z., Machova, R., Mura, L., Zsigmond, T. 2021. Entrepreneurship Motivation in the 21 st Century in Terms of Pull and Push Factors. T-Technology Education Tem Journal Management Informatics, 10 (1), 334-342.

Chun, R. (2005). Corporate reputation: meaning and measurement. International Journal of Management Reviews, 7(2), 91-109.

International Air Transport Association, 2019. Annual report [online]. Retrieved from https://www.iata.org/contentassets/c81222d96c9a4e0bb4ff6ced0126f0bb/iata-annual-review2019.pdf

Laferty, B., \& Goldsmith, R. (1999). Corporate credibility's role in consumers' attitudes and purchase intentions when a high versus a low credibility endorser is used in the add. Journal of Business Research, 44(1), 109.

Ma, L. et al., (2019). A reliable reputation computation framework for online items in E-commerce. Journal of Network and Computer Applications, 134(1).

Madden, M., \&. Smith, A. (2010). Reputation management and social media [online]. Retrieved from http://www.pewinternet.org/2010/05/26/reputation-management-and-social-media/.

Oghazi, P. et al., (2020). From Mars to Venus: Alteration of trust and reputation in online shopping. Journal of Innovation to Knowledge.

Pires, V., \& Trez, G. (2018). Corporate reputation: A discussion on construct definition and measurement and its relation to performance. Revista de Gestão, 25(1).

Pollák, F. (2015). On-line reputačný manažment v podmienkach stredoeurópskeho virtuálneho trhu. Prešov. Bookman. (Slovak).

Pollák, F., Soviar, J., Vodák, J., Holubčík, M., \& Rechtorík, M. (2019). The Presentation of Automotive Brands in the On-Line Environment-The Perspective of KIA, Peugeot, Toyota and VW in the Slovak Republic. Sustainability, 11(7), 1-21.

Reputation Institute, 2011. The RepTrak System [online]. Retrieved from http://www.reputationinstitute.com/

Riquelme, I. et al., (2019). The Dark Side of Good Reputation and Loyalty in Online Retailing: When Trust Leads to Retaliation through Price Unfairness. Journal of Interactive Marketing, 47.

Sasko, J. (2014). Proý rebrícek online reputácie slovenských firiem[online]. Podnikajte.sk Retrieved from http://www.podnikajte.sk/manazment-marketing/c/1809/category/marketing/article/rebricekonline-reputacie.xhtml

Socialbakers, 2016. Social Media Marketing Statistics [online] Retrieved from http://socialbakers.com

Song KH, Choi S, Han IH. Competitiveness Evaluation Methodology for Aviation Industry Sustainability Using Network DEA. Sustainability, 12(24).

Štefko, R., Bačík, R., \& Fedorko, R. (2017). City marketing and its impact on income sources of the local government. Polish Journal of Management Studies, 15(1).

Štefko, R., \& Pollák, F. (2016). Multi-factor analysis of online reputation as a tool for enhancing competitiveness of selected Slovak towns. European Journal of Science and Theology, 12(5).

Taeuscher, K. (2019). Reputation and new venture performance in online markets: The moderating role of market crowding. Journal of Business Venturing, 34(6).

Turner, M. (2004). Reputation, Risks and Governance. Effective Risk and Business Management Topic Paper, 6(1), 3.

Vance, P.S., \& De Angelo, C.F. (2007). Reputação Corporativa: Uma Revisão Teórica. Revista de Gestão, 14(4), 93-108.

Wang, Z., \& Chen, Q. (2020). Monitoring online reviews for reputation fraud campaigns. Knowledge-Based Systems, 195. 
INTERNATIONAL JOURNAL OF ENTREPRENEURIAL KNOWLEDGE

Issue 1, volume 9, ISSN 2336-2960 (Online)

www.ijek.org

Xu, Y. et al., (2018). Optimal control of an online reputation dynamic feedback incentive model. Communications in Nonlinear Science and Numerical Simulation, 63(1).

Zraková, D., Demjanovičová, M., \& Kubina,M.., (2019). Online reputation in the transport and logistics field. Transportation Research Procedia, 40(1).

Zigan, K. (2013). A contingency approach to the strategic management of intangible resources. Journal of General Management, 38(2), 79-99.

\section{BRIEF DESCRIPTION OF AUTHOR/AUTHORS:}

Ing. Ludovít Nastisin, PhD.

ORCID ID: 0000-0002-4403-7580

Affiliation: Department of Marketing and International Trade, Faculty of Management, University of Prešov, Konštantínova 16, Prešov, Slovakia, https://www.unipo.sk/fakulta-manazmentu

Email: ludovit.nastisin@unipo.sk

Ing. Ludovít Nastišin, PhD. in his research work, he focused primarily on cocial media marketing, online reputation, brand management, and marketing management.

\section{prof. Ing. Beata Gavurova, Ph.D. MBA.}

ORCID ID: 0000-0002-0606-879X

Affiliation: Faculty of Mining, Ecology, Process Control and Geotechnologies,

Technical University of Košice, Letná 9, 04200 Slovakia, https://uzz.fberg.tuke.sk/oddeleniemanazerstva-zemskych-zdrojov-omzz/

Email: beata.gavurova@tuke.sk

Prof. Beáta Gavurová, PhD. MBA in her research work she has focused primarily on health policy, efficiency measurement and digitalization of health care processes.

doc. PhDr. Radovan Bacik, PhD., MBA, LL.M.

ORCID ID: 0000-0002-5780-3838

Affiliation: Department of Marketing and International Trade, Faculty of Management, University of Prešov, Konštantínova 16, Prešov, Slovakia, https://www.unipo.sk/fakulta-manazmentu

Email: radovan.bacik@unipo.sk

Doc. PhDr. Radovan Bačík, PhD., MBA, LL.M. in his research work he has focused primarily on ebusiness, e-commerce, online reputation and social marketing.

\section{Mgr. Nella Svetozarovova, PhD.}

ORCID ID: 0000-0003-4899-2013

Affiliation: Department of Management, Faculty of Management, University of Prešov, Konštantínova 16, Prešov, Slovakia, https://www.unipo.sk/fakulta-manazmentu

Email: nella.svetozarovova@unipo.sk

Mgr. Nella Svetozarovová, PhD. in her research work she has focused primarily on management, performance, efficiency, marketing management and human resources.

doc. Mgr. Richard Fedorko, PhD.

ORCID ID: 0000-0003-3520-1921

Affiliation: Department of Marketing and International Trade, Faculty of Management, University of Prešov, Konštantínova 16, Prešov, Slovakia, https://www.unipo.sk/fakulta-manazmentu

Email: richard.fedorko@unipo.sk

Doc. Mgr. Richard Fedorko, PhD. in his research work he has focused primarily on marketing communication, e-business, e-marketing, branding and social media marketing. 